\title{
EFEK SAMPING KEMOTERAPI BERBASIS KARBOPLATIN TERHADAP FUNGSI GINJAL PADA PASIEN KANKER GINEKOLOGI
}

\author{
Djoko Heri Hermanto* Elly Mayangsari ${ }^{* *}$, Aulia Putri Fadriyana***凹
}

\begin{abstract}
Abstrak
Karboplatin merupakan regimen platinum terapi lini pertama pada pengobatan kanker ginekologi. Karboplatin analog dengan cisplatin, tetapi lebih stabil dan memiliki lebih sedikit efek samping. Namun, pemberian karboplatin dalam jangka panjang dapat meningkatkan akumulasinya pada tubuh sehingga meningkatkan efek samping, salah satunya pada ginjal. Tujuan penelitian ini untuk mengetahui efek samping kemoterapi berbasis karboplatin terhadap fungsi ginjal pada pasien kanker ginekologi di RSUD Dr. Saiful Anwar Malang, dengan parameter penurunan laju filtrasi glomerulus (LFG) dan peningkatan kadar blood urea nitrogen (BUN). Desain penelitian adalah analitik observasional cross-sectional dengan mengumpulkan data rekam medis dari pasien kanker ginekologi. Jumlah subjek diperoleh 45 pasien yang memenuhi kriteria inklusi dan eksklusi. Karakteristik subjek penelitian menunjukkan bahwa sebagian besar pasien dalam rentang usia 40-49 dan 50-59 tahun masing -masing sebanyak 15 pasien (33,33\%). Berdasarkan hasil uji t berpasangan diketahui bahwa tidak ada penurunan yang signifikan pada LFG pre dan post kemoterapi $(p=0,254)$ sedangkan berdasarkan hasil uji Wilcoxon didapatkan tidak ada peningkatan yang signifikan pada kadar BUN pre dan post kemoterapi $(p=0,498)$. Dari hasil penelitian, dapat disimpulkan bahwa tidak terdapat penurunan laju filtrasi glomerulus (LFG) dan peningkatan kadar BUN pada pasien kanker ginekologi yang mendapat kemoterapi berbasis karboplatin sebanyak 6 siklus di RSUD Dr. Saiful Anwar Malang.
\end{abstract}

Kata kunci: blood urea nitrogen (BUN), kemoterapi berbasis karboplatin, kanker ginekologi, laju filtrasi glomerulus (LFG)

\section{THE SIDE EFFECTS OF CARBOPLATIN-BASED CHEMOTHERAPY ON KIDNEY FUNCTION IN GYNECOLOGIC CANCER PATIENTS}

\begin{abstract}
Carboplatin is the first-line platinum therapy regimen in the treatment of gynecologic cancer. Carboplatin is analogous to cisplatin, but more stable and has fewer side effects. However, giving carboplatin for a long time can increase its accumulation in the body thereby increasing the side effects, such as on the kidney. The purpose of this study was to determine the side effects of carboplatin-based chemotherapy on kidney function in gynecologic cancer patients which were observed in decreasing glomerular filtration rate (GFR) and increasing blood urea nitrogen (BUN) level. This was a cross-sectional observational analytic research using the medical record data of gynecologic cancer patients. The number of subjects is 45 patients who qualify for the inclusion and exclusion criteria. The characteristic of the study subjects showed that most of the patients in the age range 40-49 and 50-59 years which are 15 patients (33.33\%) of each. Based on the result of the paired $t$ test, it was found that there was no significant decrease in the pre and post-chemotherapy of GFR $(p=0.254)$, while by the Wilcoxon test, there was no significant increase between pre and post BUN $(p=0.498)$. It can be concluded that there was no decrease in glomerular filtration rate (GFR) and no increase in BUN in gynecologic cancer patients who received 6 cycles of carboplatin-based chemotherapy at Dr. Saiful Anwar Malang Hospital.
\end{abstract}

Keywords: blood urea nitrogen (BUN), carboplatin-based chemotherapy, glomerular filtration rate (GFR), gynecologic cancer

* Departemen IImu Penyakit Dalam, Fakultas Kedokteran, Universitas Brawijaya

** Laboraturium Farmakologi, Fakultas Kedokteran, Universitas Brawijaya

${ }^{* * *}$ Program Studi Sarjana Kedokteran (S1), Fakultas Kedokteran, Universitas Brawijaya

E-mail: putrifadriyana@student.ub.ac.id 


\section{Pendahuluan}

Kanker merupakan penyebab kedua kematian utama di seluruh dunia. Pada tahun 2018, 9.6 juta jiwa meninggal akibat kanker di dunia. Setidaknya 1 dari 6 kematian disebabkan oleh kanker. Pada tahun 2012, kanker menjadi penyebab kematian sekitar 8,2 juta orang. Kanker ginekologi merupakan salah satu jenis kanker pada wanita dengan tingkat mortalitas yang tinggi. ${ }^{1}$ Berdasarkan estimasi GLOBOCAN pada tahun 2018, insiden kanker ginekologi terbanyak adalah kanker serviks, kanker ovarium, kanker corpus uteri, dan kanker endometrium. ${ }^{2}$ Namun, pada penelitian ini, kanker serviks dieksklusi karena dalam perkembangan kankernya, didapatkan obstruksi uropati dan hidronefrosis yang merupakan komplikasi pada gangguan fungsi ginjal. ${ }^{3}$ Salah satu pengobatan yang banyak diberikan kepada pasien kanker ginekologi adalah pemberian kemoterapi.

Obat kemoterapi digunakan utamanya untuk membunuh sel kanker dan menghambat perkembangannya. Prinsip dasar dari kemoterapi yaitu segolongan obat-obatan yang memiliki efek sitotoksik sehingga dapat menghambat pertumbuhan kanker bahkan ada yang dapat membunuh sel kanker. Kemoterapi bekerja dengan cara merusak DNA dari sel-sel yang membelah dengan cepat. Tujuan pengobatan kemoterapi tergantung pada jenis kanker dan fasenya saat didiagnosis. Beberapa kanker mempunyai penyembuhan yang dapat diperkirakan atau dapat sembuh dengan pengobatan kemoterapi. Pada kondisi lain, pengobatan mungkin hanya diberikan untuk mencegah kanker yang kambuh, ini disebut pengobatan adjuvant. ${ }^{4}$ Jika kanker menyebar luas dan dalam fase akhir, kemoterapi digunakan sebagai paliatif untuk memberikan kualitas hidup yang lebih baik. ${ }^{5}$
Kemoterapi regimen platinum masih menjadi kombinasi terapi sistemik untuk berbagai macam tumor solid karena kemampuannya dalam menurunkan risiko kambuh (recurrent) dari kanker setelah tindakan bedah kuratif pada beberapa kasus, atau memperpanjang survival pada advance disease. ${ }^{6}$ Ada tiga obat berbasis platinum yang digunakan di seluruh dunia untuk pengobatan kanker yaitu cisplatin, karboplatin, dan oxaliplatin. $^{7}$

Karboplatin utamanya digunakan pada pengobatan kanker endometrium, kanker ovarium, tumor otak, dan tumor sel germinal. 8 Sasaran utama karboplatin adalah DNA interstrand dan intrastrand sel tumor, yang mengikat secara efisien sehingga menghambat replikasi dan transkripsi serta mendorong kematian sel. Jumlah kemoterapi yang diberikan kepada pasien tergantung pada jenis tumor atau kankernya. Rata-rata pemberian kemoterapi yakni 3-6 siklus. Namun, untuk high-grade tumor, pemberian kemoterapi direkomendasikan sebanyak 6 siklus. ${ }^{7}$ Karboplatin analog dengan cisplatin. Perbedaannya yakni karboplatin lebih stabil dan memiliki lebih sedikit nefrotoksisitas, neurotoksisitas, ototoksisitas, dan emetogenesis. Namun, pemberian karboplatin dalam jangka panjang dapat meningkatkan akumulasinya pada tubuh sehingga meningkatkan efek samping dan menghasilkan toksisitas pada berbagai organ, salah satunya ginjal. $^{9}$

Ginjal rentan terhadap perkembangan toksisitas obat karena perannya dalam metabolisme dan ekskresi agen toksik. Tingginya tingkat pengiriman dan penyerapan menghasilkan konsentrasi intraseluler yang tinggi dari berbagai zat yang kemudian mengalami metabolisme yang luas, yang mengarah pada pembentukan metabolit toksik yang berpotensi dan spesies oksigen reaktif (ROS). ${ }^{10}$ 
Sitotoksisitas dari karboplatin dimediasi oleh platinum-DNA monoadducts, intra, serta interstrand diadducts, yang terbentuk setelah obat masuk ke dalam inti sel. Karboplatin secara dominan berinteraksi dengan nukleotida guanin dan adenin untuk membentuk monoadduct Pt-DNA, kemudian bereaksi dengan nukleotida kedua untuk membentuk diadduct Pt-DNA intra dan interstrand yang bersifat toksik. Akumulasi Pt-DNA diadduct pada ginjal dan terbentuknya ikatan kovalen platinum pada protein ginjal mengakibatkan penurunan aktivitas enzim antioksidan ginjal dan ekspresi protein serta penipisan glutation. Kerusakan enzim antioksidan ini dapat menyebabkan kelebihan produksi anion superoksida dan peroksida organik dalam jaringan ginjal yang menyebabkan kerusakan oksidatif. ${ }^{11}$

Penghambatan aktivitas enzim antioksidan dalam ginjal setelah pemberian karboplatin dosis tinggi mungkin dikarenakan oleh: (1) pengikatan langsung karboplatin ke kelompok sulfhidril esensial dari enzim ini (2) peningkatan spesies oksigen reaktif dan peroksida organik yang menonaktifkan enzim antioksidan, dan/ atau (3) penipisan tembaga dan seng yang penting untuk aktivitas superoksida dismutase (SOD). Superoksida dismutase memulung spesies oksigen reaktif dengan mengkatalisis pemecahan superoksida menjadi $\mathrm{H}_{2} \mathrm{O}_{2}$ dan $\mathrm{O}_{2}$. Apabila spesies reaktif oksigen semakin banyak, maka dapat terjadi akumulasi melalui ikatan kovalen pada membran tubulus ginjal dan terjadi kerusakan atau disebut juga dengan stres oksidatif. ${ }^{11,12}$ Salah satu pemeriksaan fungsi ginjal yang dapat dilakukan adalah dengan menghitung laju filtrasi ginjal dan blood urea nitrogen (BUN). ${ }^{10}$

Laju filtrasi glomerulus (LFG) merupakan suatu pemeriksaan untuk menilai fungsi ekskresi ginjal, dengan cara menghitung banyaknya filtrat yang dapat dihasilkan oleh glomerulus. Derajat penurunan nilai LFG menandakan beratnya kerusakan ginjal. Di sisi lain, peningkatan dari kadar blood urea nitrogen (BUN) juga dapat menjadi parameter yang digunakan untuk menunjukkan adanya penurunan fungsi ginjal. 13,14

Modalitas utama pengobatan kemoterapi pada kanker ginekologi di RSUD Dr. Saiful Anwar Malang menggunakan karboplatin sehingga mayoritas pasien kanker ginekologi yang tidak memiliki kontraindikasi mendapatkan karboplatin dan belum ada penelitian sebelumnya yang menganalisis efek sampingnya pada fungsi ginjal. Penelitian ini bertujuan untuk menganalisis efek samping pemberian karboplatin terhadap ginjal dengan parameter laju filtrasi glomerulus dan kadar blood urea nitrogen pada pasien kanker ginekologi RSUD Dr. Saiful Anwar Malang.

\section{Bahan dan Metode}

Penelitian ini merupakan penelitian analitik observasional dengan pendekatan metode cross-sectional dengan cara mengumpulkan data sekunder dari rekam medis di RSUD Dr. Saiful Anwar Malang. Penelitian ini dilakukan di Divisi Hematologi Onkologi Medik dan Ruang Rekam Medis RSUD Dr. Saiful Anwar Malang pada bulan Januari 2020 hingga Juli 2020 dan telah dinyatakan laik etik oleh Komisi Etik Penelitian Kesehatan RSUD. Dr. Saiful Anwar Malang dengan nomor 400/061/K.3/302/2020.

Populasi penelitian adalah pasien yang menjalani kemoterapi di RSUD Dr. Saiful Anwar Malang. Sampel penelitian adalah pasien penderita kanker ginekologi yang menjalani kemoterapi berbasis karboplatin di RSUD Dr. Saiful Anwar Malang pada tahun 2017-2020.

Adapun sampel penelitian harus memenuhi kriteria inklusi, antara lain: 1) Pasien kanker ginekologi RSUD Dr. Saiful Anwar Malang yang diberi kemoterapi berbasis karboplatin; 
2) Pasien menjalani kemoterapi pada periode tahun 2017-2020. Kriteria eksklusi yakni, 1) Pasien kanker serviks; 2) Pasien sudah menderita penyakit ginjal (seperti batu ginjal) atau mengalami gangguan fungsi ginjal sebelum diberikan kemoterapi berbasis karboplatin; 3) Pasien tidak melanjutkan kemoterapi hingga seri ke 6 (meninggal dunia, terkendala biaya atau efek samping obat yang menyebabkan dokter memutuskan menghentikan pengobatan); 4) Pasien dengan diabetes mellitus; 5) Pasien dengan hipertensi.

Pemilihan sampel penelitian menggunakan teknik consecutive sampling yakni peneliti memilih sampel yang memenuhi kriteria khusus (berdasarkan kriteria inklusi dan eksklusi) penelitian sampai kurun waktu tertentu sampai jumlah sampel yang dibutuhkan terpenuhi.

Jumlah minimal sampel pada penelitian ini dihitung menggunakan rumus uji komparatif satu populasi data berpasangan. Berdasarkan perhitungan besar minimal sampel, didapatkan hasil minimal sampel penelitian adalah 35 sampel dan didapatkan jumlah sampel yang memenuhi kriteria inklusi dan eksklusi sebanyak 45 pasien.

Instrumen penelitian yang digunakan yaitu lembar CRF (case research form) yang digunakan untuk mencatat data pasien yang dibutuhkan yaitu nama pasien, usia, jenis kelamin, nomor rekam medis, nomor billing, diagnosis saat masuk rumah sakit, diagnosis kanker ginekologi yang ditegakkan oleh dokter penanggung jawab, data tanggal siklus pertama dan siklus keenam, hasil laboraturium faal ginjal yakni data ureum dan serum kreatinin sebelum siklus pertama dan keenam kemoterapi berbasis karboplatin.

Analisis data meliputi uji normalitas dan uji komparatif. Pada uji normalitas, dilihat apakah data terdistribusi normal atau tidak untuk menentukan uji komparatif yang digunakan. Uji normalitas data yang digunakan yakni uji Shapiro-Wilk karena jumlah sampel di bawah 50 sampel. Uji komparatif digunakan untuk melihat apakah ada perbedaan yang siginifikan dari 2 kondisi (pre dan post kemoterapi). Uji komparatif menggunakan uji $t$ berpasangan apabila data terdistribusi normal dan menggunakan uji Wilcoxon apabila data tidak terdistribusi normal. Besarnya pengaruh variabel bebas terhadap variabel terikat dinyatakan dengan interval kepercayaan dan nilai $p$ dianggap bermakna apabila $p<0,05$.

\section{Hasil}

Data penelitian ini didapatkan dari rekam medis pasien terdiagnosis kanker ovarium, kanker endometrium, kanker vagina, dan kanker corpus uteri yang menjalani kemoterapi dengan regimen karboplatin selama 6 siklus dengan jarak antar siklus yaitu 21 hari. Kemudian perhitungan laju filtrasi glomerulus (LFG) menggunakan rumus CKD-EPI dari perolehan data jenis kelamin, usia, ras, dan serum kreatinin pasien. Sementara, kadar blood urea nitrogen (BUN) pre (sebelum siklus pertama kemoterapi) dan post (sebelum siklus keenam kemoterapi) dihitung dari perolehan data ureum pasien dibagi dengan 2,14.15

Hasil penelitian mendapatkan bahwa seluruh subjek penelitian adalah pasien wanita $(100 \%)$ oleh karena pada penelitian ini dibahas mengenai efek samping karboplatin pada pasien kanker ginekologi. Selanjutnya, karakteristik pasien berdasarkan usia dan kombinasi kemoterapi didapatkan usia paling banyak yakni dalam rentang usia 40-49 tahun yaitu sebanyak 15 orang $(33,33 \%)$ dan rentang usia 50-59 tahun sebanyak 15 orang $(33,33 \%)$. Terdapat 21 pasien $(46,67 \%)$ yang diberikan kemoterapi kombinasi karboplatin-paclitaxel dan 24 pasien $(53,33 \%)$ dengan kemoterapi kombinasi karboplatin-docetaxel (Tabel 1). 
Tabel 1. Karakteristik subjek penelitian

\begin{tabular}{lcc}
\hline \multicolumn{1}{c}{ Karakteristik } & Frekuensi & Persentase (\%) \\
\hline $\begin{array}{l}\text { Jenis Kelamin } \\
\text { Wanita }\end{array}$ & 45 & 100 \\
Usia (Tahun) & 1 & 2,22 \\
$<20$ & 0 & 0 \\
$20-29$ & 4 & 8,89 \\
$30-39$ & 15 & 33,33 \\
$40-49$ & 15 & 33,33 \\
$50-59$ & 8 & 17,78 \\
$60-69$ & 2 & 4,45 \\
$>=70$ & 21 & 46,67 \\
Kombinasi Kemoterapi & 24 & 53,33 \\
$\quad$ Karboplatin-Paclitaxel & & 100 \\
Karboplatin-Docetaxel & 45 & \\
Total &
\end{tabular}

Laju Filtrasi Glomerulus (LFG) Pre dan Post Kemoterapi

Berdasarkan Tabel 2, dapat diketahui bahwa distribusi laju filtrasi glomerulus pre kemoterapi terbanyak pada kategori normal $(\geq 90)$ yakni sebanyak $32(71,11 \%)$ pasien, diikuti kategori menurun ringan (60-89) yakni sebanyak $12(26,67 \%)$ pasien, dan kategori menurun ringan hingga sedang (45-59) yakni sebanyak 1 $(2,22 \%)$ pasien. Sedangkan pada distribusi laju filtrasi glomerulus post kemoterapi terbanyak yaitu pada kategori normal $(\geq 90)$ sebanyak 30 $(66,67 \%)$ pasien, diikuti kategori menurun ringan (60-89) yakni sebanyak 13 (28,89\%) pasien, dan kategori menurun ringan hingga sedang (45-59) yakni sebanyak 2 (4,44\%) pasien.

Pada Tabel 3, dapat diketahui hasil uji normalitas Shapiro-Wilk laju filtrasi glomerulus menunjukkan nilai $p=0,164(p>0,05)$ pada data LFG pre kemoterapi dan nilai $p=0,537$ ( $p$ $>0,05)$ pada data LFG post kemoterapi sehingga disimpulkan bahwa data laju filtrasi glomerulus pre kemoterapi dan post kemoterapi terdistribusi normal, sehingga uji komparatif yang digunakan yakni uji t berpasangan.

Tabel 2. Distribusi laju filtrasi glomerulus (LFG) pre dan post kemoterapi

\begin{tabular}{lcc}
\hline \multicolumn{1}{c}{ LFG $\left(\mathrm{mL} / \mathrm{min} / 1,73 \mathrm{~m}^{2}\right)$} & LFG Pre Kemoterapi & LFG Post Kemoterapi \\
\hline$\geq 90$ & $32(71,11 \%)$ & $30(66,67 \%)$ \\
(Normal atau Tinggi) & $12(26,67 \%)$ & $13(28,89 \%)$ \\
$\begin{array}{l}60-89 \\
\text { (Menurun Ringan) }\end{array}$ & $1(2,22 \%)$ & $2(4,44 \%)$ \\
$\begin{array}{l}45-59 \\
\text { (Menurun Ringan hingga Sedang) }\end{array}$ & 0 & 0 \\
$\begin{array}{l}30-44 \\
\text { (Menurun Sedang hingga Berat) }\end{array}$ & 0 & 0 \\
$\begin{array}{l}\text { 15-29 } \\
\text { (Menurun Berat) }\end{array}$ & 0 & 0 \\
$\begin{array}{l}<15 \\
\text { (Gagal Ginjal) }\end{array}$ & $45(100 \%)$ & $45(100 \%)$ \\
Total & & \\
\hline
\end{tabular}


Tabel 3. Uji normalitas laju filtrasi glomerulus (LFG) pre dan post kemoterapi

\begin{tabular}{lccc}
\hline & Statistic & df & Sig. (p) \\
\hline LFG pre kemoterapi & 0,963 & 45 & 0,164 \\
LFG post kemoterapi & 0,978 & 45 & 0,537 \\
\hline
\end{tabular}

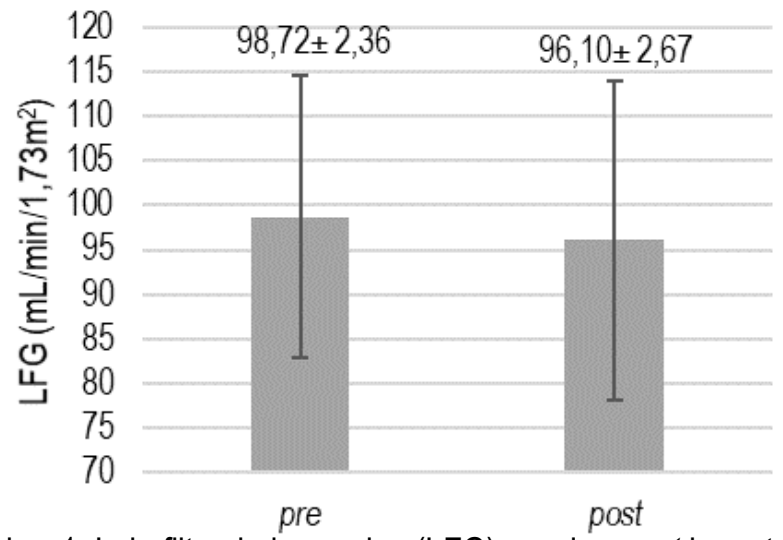

Gambar 1. Laju filtrasi glomerulus (LFG) pre dan post kemoterapi

Berdasarkan Gambar 1, dapat diketahui bahwa rerata laju filtrasi glomerulus pre kemoterapi yaitu $98,72 \pm 2,36 \mathrm{~mL} / \mathrm{min} / 1,73 \mathrm{~m}^{2}$ dan rerata laju filtrasi glomerulus post kemoterapi yaitu $96,10 \pm 2,67 \mathrm{~mL} / \mathrm{min} / 1,73 \mathrm{~m}^{2}$. Dari sini tampak bahwa terdapat penurunan rerata laju filtrasi glomerulus setelah pemberian kemoterapi berbasis karboplatin sebesar 2,62 $\mathrm{mL} / \mathrm{min} / 1,73 \mathrm{~m}^{2}(p=0,254 ; p>0,05)$. Hal ini menunjukkan bahwa pemberian kemoterapi berbasis karboplatin sebanyak 6 siklus pada kanker ginekologi belum mengakibatkan penurunan yang signifikan secara statistik terhadap laju filtrasi glomerulus.

Kadar Blood Urea Nitrogen (BUN) Pre dan Post Kemoterapi

Berdasarkan Tabel 4, dapat diketahui bahwa distribusi kadar BUN pre kemoterapi terbanyak pada kategori normal (7-21) yakni sebanyak $41(91,11 \%)$ pasien, diikuti nilai kadar BUN <7 yakni sebanyak 4 (8,89\%) pasien. Sedangkan pada distribusi kadar BUN post kemoterapi terbanyak yaitu pada kategori normal (7-21) yakni sebanyak 38 (84,44\%) pasien, diikuti kadar BUN $<7$ yakni sebanyak 4 $(8,89 \%)$ pasien, dan kadar $>21$ yakni sebanyak $3(6,67 \%)$ pasien.

Berdasarkan Tabel 5, dapat diketahui hasil uji normalitas Shapiro-Wilk kadar BUN menunjukkan nilai $p=0,033(p<0,05)$ pada data BUN pre kemoterapi dan nilai $p=0,000(p<$ $0,05)$ pada data kadar BUN post kemoterapi sehingga data tidak terdistribusi normal. Oleh karena itu, uji komparatif yang akan digunakan yakni uji Wilcoxon.

Berdasarkan Gambar 2, dapat diketahui bahwa rerata kadar BUN pre kemoterapi yaitu $10,58 \pm 0,5 \mathrm{mg} / \mathrm{dL}$ dan rerata kadar BUN post kemoterapi yaitu $11,52 \pm 0,81 \mathrm{mg} / \mathrm{dL}$. Namun, peningkatan rerata kadar BUN setelah pemberian kemoterapi berbasis karboplatin sebesar $0,94 \mathrm{mg} / \mathrm{dL}(p=0,498 ; p>0,05)$ menunjukkan bahwa pemberian kemoterapi berbasis karboplatin sebanyak 6 siklus pada kanker ginekologi belum mengakibatkan peningkatan yang signifikan terhadap kadar BUN. 
Tabel 4. Distribusi blood urea nitrogen (BUN) pre dan post kemoterapi

\begin{tabular}{lcc}
\hline Kadar BUN (mg/dL) & Pre Kemoterapi & Post Kemoterapi \\
\hline$<7$ & $4(8,89 \%)$ & $4(8,89 \%)$ \\
$7-21$ (Normal) & $41(91,11 \%)$ & $38(84,44 \%)$ \\
$>21$ & 0 & $3(6,67 \%)$ \\
Total & $45(100 \%)$ & $45(100 \%)$ \\
\hline
\end{tabular}

Tabel 5. Uji normalitas blood urea nitrogen (BUN) pre dan post kemoterapi

\begin{tabular}{lccc}
\hline & Statistic & df & Sig. (p) \\
\hline BUN pre kemoterapi & 0,945 & 45 & $0,033^{*}$ \\
BUN post kemoterapi & 0,891 & 45 & $0,000^{*}$ \\
\hline
\end{tabular}

Keterangan: $\left({ }^{*}\right)$ signifikan $p<0,05$

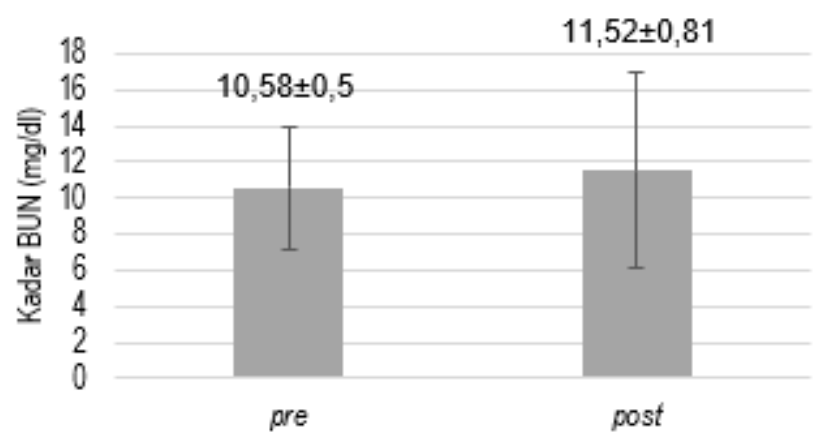

Gambar 2. Kadar blood urea nitrogen (BUN) pre dan post kemoterapi

\section{Pembahasan}

Pada penelitian ini keseluruhan subjek adalah wanita (100\%) dan didapatkan 13 pasien memiliki kadar laju filtrasi glomerulus pre di bawah nilai normal, meskipun kadar serum kreatinin pre semua pasien masih dalam rentang normal. Hal ini sesuai dengan penelitian sebelumnya yang menerangkan bahwa penurunan laju filtrasi glomerulus lebih cepat terjadi pada wanita. ${ }^{16}$ Penelitian lain juga menjelaskan bahwa penurunan laju filtrasi glomerulus pada wanita lebih cepat. Pada wanita dewasa muda diketahui laju filtrasi glomerulus lebih tinggi daripada laki-laki melalui skala BSA, sehingga menyebabkan penurunan laju filtrasi glomerulus yang lebih cepat, mirip dengan yang terlihat pada patologi ginjal terkait hiperfiltrasi. ${ }^{17}$ Selain itu, seiring bertambahnya usia, dampak penurunan kadar estrogen pada wanita secara bertahap akan mempengaruhi hemodinamik dan hilangnya struktur ginjal. ${ }^{18}$ Selain itu, sejalan dengan penelitian lain bahwa kadar blood urea nitrogen (BUN) tidak menunjukkan perbedaan yang signifikan antara wanita dan laki-laki. ${ }^{19}$

Pada penelitian ini didapatkan usia terbanyak adalah pada rentang 40-49 tahun $(33,33 \%)$ dan $50-59$ tahun $(33,33 \%)$ dan usia rerata pasien adalah 51 tahun. 
Hasil penelitian lain juga menunjukkan bahwa nefrotoksisitas karboplatin pada kanker ginekologi didapatkan paling banyak pada pasien berusia 55 tahun. ${ }^{20}$ Penelitian oleh Busmar (2010) dan Gea et al. (2015) juga menunjukkan bahwa insiden kanker ovarium jarang ditemukan pada usia di bawah 40 tahun dan usia terbanyak pasien kanker ovarium yaitu usia $\geq 51$ tahun $(46,32 \%) .{ }^{21,22}$

Penelitian oleh Fenton et al. (2018) menunjukkan bahwa rerata laju filtrasi glomerulus pada dewasa muda yaitu sekitar $100 \mathrm{~mL} / \mathrm{menit} / 1,73 \mathrm{~m}^{2}$ hingga usia 35 tahun, lalu mengalami penurunan seiring bertambahnya usia dan lebih cepat terjadi pada wanita. Batas bawah kisaran normal laju filtrasi glomerulus mulai turun menjadi $60 \mathrm{~mL} /$ menit/1,73 $\mathrm{m}^{2}$ terjadi pada usia 50 tahun pada wanita dan usia 55 tahun pada laki-laki. ${ }^{16}$ Penurunan laju filtrasi glomerulus seiring bertambahnya usia juga terjadi pada orang yang sehat. Hal ini karena terjadinya perubahan fisiologis seperti pada aliran darah ginjal dan perubahan struktural seperti pada penurunan jumlah nefron, glomerulosclerosis, dan fibrosis tubulointerstital. 23

Adanya temuan pada 3 orang pasien yang memiliki kadar BUN di atas rentang normal kadar BUN dewasa, dapat disebabkan oleh faktor usia yaitu rerata usia 57,33 tahun. Rentang normal kadar BUN akan berbeda pada usia muda dan usia dewasa. Pada usia lebih dari 60 tahun akan memiliki nilai normal BUN yang lebih tinggi. 24,25

Pada penelitian ini, 21 sampel mendapatkan kemoterapi kombinasi karboplatin-paclitaxel dan 24 sampel mendapatkan kemoterapi kombinasi karboplatin-docetaxel. Paclitaxel dan docetaxel merupakan jenis kemoterapi golongan taxan yang memiliki mekanisme kerja berikatan dengan mikrotubuler sel sehingga terjadi disolusi struktur mitotic spindle dan mencegah terjadinya replikasi sel. Docetaxel serupa dengan paclitaxel, namun memiliki keunggulan pada efek farmakologi dan farmakokinetik serta menjadi terapi alternatif kemoterapi pada pasien dengan resistensi paclitaxel. 26

Namun, banyak dilaporkan efek samping pada pemberian golongan taxan yaitu lemas (fatigue) (27-74\%), myalgia (23-33\%), nyeri sendi/arthralgia $(20-30 \%)$, mual $(20-45 \%)$, neuropati sensoris perifer simetris (20-64\%), dan neutropenia (45-95\%). ${ }^{27-29}$ Selain itu, diketahui bahwa paclitaxel, ifosfamide dan nedaplatin merupakan kemoterapi yang aman dan efektif yang menghasilkan lebih sedikit nefrotoksisitas pada pasien tumor sel germinal dengan disfungsi ginjal. ${ }^{30}$ Oleh karna itu, apabila terdapat penurunan fungsi ginjal pada penelitian ini, maka kemungkinan besar disebabkan oleh karboplatin, bukan karena efek dari paclitaxel atau docetaxel.

Pada penelitian ini, didapatkan penurunan laju filtrasi glomerulus sebesar 2,61 mL/ menit/1,73 $\mathrm{m}^{2}$ pada pre dan post kemoterapi, namun secara statistik tidak berbeda bermakna $(p=0,254 ; p>0,05)$ (Tabel 2 dan 3). Hal ini menunjukkan bahwa pemberian karboplatin sebanyak 6 siklus pada kanker ginekologi belum mengakibatkan penurunan laju filtrasi glomerulus. Sejalan dengan hasil penelitian Elborai et al. (2020) yang menemukan sebanyak $3 \%$ pasien mengalami penurunan laju filtrasi glomerulus menjadi kategori menurun ringan $\left(60-89 \mathrm{~mL} / \mathrm{menit} / 1,73 \quad \mathrm{~m}^{2}\right)$ setelah pemberian karboplatin. ${ }^{31}$ Pada penelitian oleh Bergeron et al. (2005) juga mendapatkan hasil hanya 1 dari 30 pasien yang mengalami penurunan laju filtrasi glomerulus $<89 \mathrm{~mL} /$ menit/1,73 m2 setelah pemberian karboplatin. ${ }^{32}$

Pada penelitian ini, pasien mendapatkan dosis karboplatin dalam rentang 250-600 mg/m² yang masih tergolong dalam dosis lowmoderate karboplatin yang secara normal banyak digunakan di klinis. 
Hal ini serupa dengan hasil penelitian lain yang tidak menunjukkan penurunan laju filtrasi glomerulus secara signifikan pada dosis pemberian karboplatin $300-500 \mathrm{mg} / \mathrm{m}^{2} .34,35$ Karboplatin akan mulai memberikan efek samping nefrotoksisitas apabila diberikan pada dosis yang tinggi.31,33 Penelitian lain yang melihat pasien kanker ovarium dengan pemberian kemoterapi single-agent karboplatin dosis tinggi dengan dosis inisial $1 \mathrm{~g} / \mathrm{m}^{2}$ pada $500 \mathrm{ml} \mathrm{5 \%}$ dextrose, didapatkan adanya perbedaan yang signifikan antara laju filtrasi glomerulus sebelum pemberian karboplatin dengan setelah pemberian karboplatin siklus akhir dengan penurunan rerata laju filtrasi glomerulus $12,5 \mathrm{ml} /$ menit. Namun, tidak ada perbedaan yang nyata dari laju filtrasi glomerulus sebelum pemberian karboplatin dengan laju filtrasi glomerulus 3 bulan setelah siklus akhir pemberian karboplatin. ${ }^{20}$

Pada penelitian ini ditemukan adanya peningkatan yang tidak signifikan terhadap rerata kadar blood urea nitrogen (BUN) setelah pemberian karboplatin sebanyak 6 siklus pada kanker ginekologi yaitu sebesar $0,94 \mathrm{mg} / \mathrm{dL}(\mathrm{p}=$ 0,498; $p>0,05)$. Pada penelitian lain menunjukkan hasil yang serupa, didapatkan nilai median BUN $11 \mathrm{mg} / \mathrm{dL}$ setelah pemberian karboplatin dosis $300-500 \mathrm{mg} / \mathrm{m}^{2} .{ }^{36}$

Peningkatan kadar BUN >21 mg/dL dapat disebabkan oleh faktor usia, diet tinggi protein, dehidrasi, syok, gagal jantung kongestif, pendarahan, dan penyakit renal, seperti gagal ginjal akut, nefritis glomerular, dan nekrosis tubuler, obstruksi saluran kemih.24,37

Beberapa penelitian menunjukkan bahwa tikus yang diinduksi karboplatin dosis rendah, didapatkan BUN dan serum kreatinin yang hampir sama dengan kontrol. Namun, pada tikus yang diinduksi karboplatin dosis tinggi terdapat peningkatan yang signifikan pada BUN dan serum kreatinin daripada tikus kontrol, dan masih lebih rendah jika dibandingkan dengan tikus yang diinduksi cisplatin. Selain itu, pada tikus yang diinduksi karboplatin dosis tinggi juga ditemukan adanya beberapa kerusakan struktur ginjal yang dilihat dari electronic supplementary material berupa hilangnya intercellular junctions dan cellular fragment detachment pada lumen tubul ginjal. Kerusakan ginjal juga berakibat pada turunnya berat badan secara dramatis pada tikus yang diinduksi karboplatin dosis tinggi. Hal ini karena poliuria yang disebabkan oleh kerusakan tubular yang mengarah pada dehidrasi, salah satu penyebab kenaikan BUN. 12,38,39

Karboplatin merupakan generasi kedua dari agen kemoterapi platinum yang dibuat lebih rendah efek nefrotoksisitas dan neuropati perifernya dibanding cisplatin, sehingga karboplatin menjadi alternatif pilihan lain dari cisplatin pada beberapa kanker dengan kondisi fungsi ginjal pasien yang menurun. 33,40-42 Hasil penelitian oleh Chen et al. (2017) menunjukkan bahwa histologi ginjal dengan pengecatan $\mathrm{HE}$ menggambarkan tidak adanya efek nefrotoksisitas karboplatin dan hasil qPCR yang menunjukkan bahwa karboplatin tidak memberikan efek pada kadar Organic Cation Transporter-2 (rOCT2) mRNA yang merupakan salah satu marker dari terjadinya nefrotoksisitas. 40 Penelitian lain menunjukkan bahwa hipomagnesia merupakan manifestasi tersering yang muncul pada nefrotoksistas karboplatin. ${ }^{42}$ Efek samping lain yang lebih sering dialami pasien adalah terjadinya myelosupresi dan efek hematologik. Efek myelosupresi karena pemberian karboplatin terjadi $20-40 \%$ dari pasien yang diberikan pengobatan karboplatin dosis konvensional dan lebih dari $90 \%$ pasien yang diberikan pengobatan karboplatin dosis tinggi. 40 


\section{Kesimpulan}

Secara keseluruhan dapat disimpulkan bahwa tidak terdapat penurunan yang signifikan laju filtrasi glomerulus (LFG) dan tidak terdapat peningkatan yang signifikan pada kadar blood urea nitrogen (BUN) pada pasien kanker ginekologi yang mendapat kemoterapi berbasis karboplatin sebanyak 6 siklus di RSUD Dr. Saiful Anwar Malang.

\section{Daftar Pustaka}

1. Pusdatin Kemenkes RI. Situasi Penyakit Kanker di Indonesia. Infodatin-Kanker. 2015. 3.

2. Bray F, Ferlay J, Soerjomataram I, Siegel RL, Torre LA, \& Jemal A. Global Cancer Statistics 2018: GLOBOCAN Estimates of Incidence and Mortality Worldwide for 36 Cancers in 185 Countries. CA Cancer J Clin. 2018; 68(6):394-424.

3. Pergialiotis V, Bellos I, Thomakos N, Haidopoulos D, Perrea DN, Kontzoglou K, \& Rodolakis A. Survival Outcomes of Patients with Cervical Cancer and Accompanying Hydronephrosis: A Systematic Review of the Literature. Oncology reviews. 2019; 13 (1):387. doi: 10.4081/oncol.2019.387.

4. Diaz-Padilla I (Editor). Ovarian Cancer: $A$ Clinical and Translational Update. IntechOpen. 2013. DOI: 10.5772/56234.

5. Takimoto $\mathrm{CH} \&$ Awada A. Safety and AntiTumor Activity of Sorafenib (Nexavar®) in Combination with Other Anti-Cancer Agents: a Review of Clinical Trials. Cancer Chemotherapy and Pharmacology. 2008; 61 (4):535-548.

6. Dorff TB, Groshen S,Garcia A, Shah M,Tsao-Wei D, Pham $H$, Cheng CW, Brandhorst S, Cohen P, Wei M, Longo V,
Quinn DI. Safety and Feasibility of Fasting in Combination with Platinum-Based Chemotherapy. BMC Cancer. 2016; 16 (360).

7. National Comprehensive Cancer Network. [Online]. 2019. Available at: https:// www.nccn.org/professionals/physician_gls/ default.aspx. Diakses 5 Desember 2019.

8. Swathi B, Bhavika D, \& Begum N. Adverse Drug Reaction Profiles of Commonly Used Platinum Compounds in Cancer Chemotherapy. Int J Basic Clin Pharmacol. 2015; 4(2):284-289.

9. Sousa GFD, Wlodarczyk SR, \& Monteiro G. Carboplatin: Molecular Mechanisms of Action Associated with Chemoresistance. Brazilian Journal of Pharmaceutical Sciences. 2014; 50(4): 693-701.

10. Noviyani R. Suwiyoga K, Anak AA, Dewi WP, Niruri R, Tunas IK, Budiana ING. Evaluasi Nilai BUN (Blood Urea Nitrogen) dan Serum Kreatinin pada Pemberian Kemoterapi Paklitaksel-Karboplatin pada Pasien Kanker Serviks dan Sel Squamousa Stadium IIB-IIIB. Jurnal Universitas Padjajaran. 2014; 3(2):55-60.

11. Hah SS, Stivers KM, de Vere White RW, Henderson PT. Kinetics of CarboplatinDNA Binding in Genomic DNA and Bladder Cancer Cells as Determined by Accelerator Mass Spectrometry. Chemical Research in Toxicology. 2006; 19(5):622-626.

12. Husain $K$, Jagannathan $R$, Hasan $Z$, Trammell GL, Rybak LP, Hazelrigg SR, Somani SM. Dose Response of Carboplatin -Induced Nephrotoxicity in Rats. Pharmacology \& Toxicology. 2002; 91 (2):83-89.

13. Dine A. Renal Physiology Anatomy and Physiology. USA: Addison Weisley; 2012. P. 78-90. 
14. Rodwell VW. Catabolism of Proteins \& of Amino Acid Nitrogen. In: Harper's Illustrated Biochemistry. 30th ed. New York: McGrawHill Education. (Online). 2015. http:// www.accessmedicine.com. Diakses 3 Desember 2019.

15. McLaughlin, R. M., \& Fish, R. E. 1994. Clinical Biochemistry and Hematology. In: The Biology of Laboratory Rabbit (pp.111127). Academic Press.

16. Fenton A, Montgomery $E$, Nightingale $P$, Peters AM, Sheerin N, Wroe AC, Lipkin GW. Glomerular Filtration Rate: New Ageand Gender-Specific Reference Ranges and Thresholds for Living Kidney Donation. BMC Nephrology. 2018; 19(1):1-8.

17. Peters AM, Perry L, Hooker CA, Howard B, Neilly MD, Seshadri N, Sobnack R, Irwin A, Snelling $H$, Gruning $T$, et al. Extracellular Fluid Volume and Glomerular Filtration Rate in 1878 Healthy Potential Renal Transplant Donors: Effects of Age, Gender, Obesity and Scaling. Nephrol Dial Transplant. 2012; 27(4):1429-1437. doi: 10.1093/ndt/gfr479.

18. Berg UB. Differences in Decline in GFR with Age between Males and Females. Reference Data on Clearances of Inulin and PAH in Potential Kidney Donors. Nephrol Dial Transplant. 2006; 21(9):2577-2582. doi: $10.1093 / \mathrm{ndt} / \mathrm{gfl} 227$.

19. Kamal A. Estimation of Blood Urea Nitrogen (BUN) and Serum Creatinine Level in Patients of Renal Disorder. Indian J Fundam Appl Life Sci. 2014; 4(4):199-202.

20. Hardy JR, Tan S, Fryatt I, Wiltshaw E. How Nephrotoxic is Carboplatin? British Journal of Cancer. 1990; 61(4):644.

21.Busmar B. Kanker Ovarium. Dalam: Onkologi Ginekologi. Aziz MF, Andrijono, Saifuddin AB (Editor). Edisi Ke-1. Jakarta: Bina Pustaka Sarwono Prawirohardjo. 2010. HIm. 468-27.
22. Gea IT, Loho MF, Wagey FW. Gambaran Jenis Kanker Ovarium di RSUP Prof. Dr. RD Kandou Manado Periode Januari 2013Desember 2015. Jurnal e-CliniC. 2016; 4 (2):1-6.

23. Glassock RJ \& Rule AD. The Implications of Anatomical and Functional Changes of the Aging Kidney: with an Emphasis on the Glomeruli. Kidney Int. 2012; 82(3):270277. doi: 10.1038/ki.2012.65.

24. Aono T, Matsubayashi K, Kawamoto A, Kimura S, Doi Y, Ozawa T. Normal Ranges of Blood Urea Nitrogen and Serum Creatinine Levels in the CommunityDwelling Elderly Subjects Aged 70 Years or Over--Correlation Between Age and Renal Function. Nihon Ronen Igakkai Zasshi. Japanese Journal of Geriatrics. 1994; 31 (3):232-236. doi:10.3143/geriatrics.31.232.

25. Lubran MM. Renal Function in the Elderly. Annals of Clinical \& Laboratory Science. 1995; 25(2):122-133.

26. Vasey PA, Jayson GC, Gordon A, Gabra H, Coleman R, Atkinson R, Kaye SB. Phase III Randomized Trial of Docetaxel-Carboplatin Versus Paclitaxel-Carboplatin as First-Line Chemotherapy for Ovarian Carcinoma. Journal of the National Cancer Institute. 2004; 96(22):1682-1691.

27.Garon EB, Ciuleanu TE, Arrieta O, Prabhash K, Syrigos KN, Goksel T, \& Czyzewicz G. Ramucirumab Plus Docetaxel Versus Placebo Plus Docetaxel for SecondLine Treatment of Stage IV Non-Small-Cell Lung Cancer after Disease Progression on Platinum-Based Therapy (REVEL): a Multicentre, Double-Blind, Randomised Phase 3 Trial. The Lancet. 2014; 384 (9944):665-673.

28. Guastalla III JP \& Dieras V. The Taxanes: Toxicity and Quality of Life Considerations in Advanced Ovarian Cancer. British Journal of Cancer. 2003; 89(3):S16-S22. 
29. Shiraishi T, Nakamura T, Takamura T, Oishi M, Yamada T, Yamada Y, Ukimura O. Less Nephrotoxicity of Paclitaxel and Ifosfamide Plus Nedaplatin for Refractory or Relapsed Germ Cell Tumors in Patients with Impaired Renal Function. International Journal of Urology. 2020; 27(2):134-139.

30. Elborai $Y$, Almutereen M, Maher OM, Hafe $H$, Lee MA, Lehmann $L$. Changes in Glomerular Filtration Rate and Clinical Course after Sequential Doses of Carboplatin in Children with Embryonal Brain Tumors Undergoing Autologous Stem Cell Transplantation. Journal of the Egyptian National Cancer Institute. 2020; 32(1):1-7.

31. Bergeron C, Dubourg L, Chastagner $P$, Mechinaud F, Plouvier E, Desfachelles AS, et al. Long-Term Renal and Hearing Toxicity of Carboplatin in Infantstreated for Localized and Unresectable Neuroblastoma: Results of the SFOPNBL90 Study. Pediatry Blood Cancer. 2005; 45 (1):32-6. https://doi.org/10.1002/pbc.20379.

32. Iwasaki K, Obara W, Kato Y, Takata R, Tanji S, Fujioka T. Neoadjuvant Gemcitabine Plus Carboplatin for Locally Advanced Bladder Cancer. Japanese Journal of Clinical Oncology. 2013; 43(2): 193-199.

33. Tait N, Abrams J, Egorin MJ, Cohen AE, Einsenbenger $M$, van Echo DA. Phase II Carboplatin for Metastatic Renal Cell Cancer with a Standard Dose and a Calculated Dose According to Renal Function. American Social Clinical Oncology. 1988; 7:A484.

34. Calvert AH, Harland SJ, Newell DR, Siddik ZH, Harrap KR. Phase I Studies with Carboplatin at the Royal Marsden Hospital. Cancer Treat. Rev. 1985; 12:1.
35. Hong CR, Kang HJ, Moon SJ, Oh J, Hong KT, Choi JY, Shin HY. Pharmacokinetics of High-Dose Carboplatin in Children Undergoing High-Dose Chemotherapy and Autologous Stem Cell Transplantation with BSA-Based Dosing. Bone Marrow Transplantation. 2020; 55(1):137-146.

36. Edmund L. Kidney Function Tests. Clinical Chemistry and Molecular Diagnosis. $4^{\text {th }}$ Edition. US: Elsevier. 2010. P.797-831.

37. Moraleja I, Esteban-Fernández D, Lázaro A, Humanes B, Neumann B, Tejedor A, Gómez-Gómez MM. Printing Metal-Spiked Inks for LA-ICP-MS Bioimaging Internal Standardization: Comparison of the Different Nephrotoxic Behavior of Cisplatin, Carboplatin, and Oxaliplatin. Analytical and Bioanalytical Chemistry. 2016; 408(9):23092318.

38. Elgendy AA \& Elsaed WM. The Role of Erythropoietin, Vitamin C and L-NAME in Carboplatin-Induced Hematological and Renal Dysfunctions. Bulletin of Egyptian Society for Physiological Sciences. 2019; 39(2):231-251.

39. Chen X, Wang J, Fu Z, Zhu B, Wang J, Guan S, Hua Z. Curcumin Activates DNA Repair Pathway in Bone Marrow to Improve Carboplatin-Induced Myelosuppression. Scientific Reports. 2017; 7(1):1-11.

40. Kim YR, Lee JL, You D, Jeong IG, Song C, Hong B, Ahn H. Gemcitabine Plus SplitDose Cisplatin Could Be a Promising Alternative to Gemcitabine Plus Carboplatin for Cisplatin-Unfit Patients with Advanced Urothelial Carcinoma. Cancer Chemotherapy and Pharmacology. 2015; 76(1):141-153.

41. Małyszko J, Kozłowska K, Kozłowski L, Małyszko J. Nephrotoxicity of Anticancer Treatment. Nephrology Dialysis Transplantation. 2017; 32(6):924-936. 